\title{
Forum prorogatum and ius cogens standards
}

\author{
Willem van Genugten *
}

On 3 February 2006, the International Court of Justice (the Court) rendered its judgement on its jurisdiction in the case Democratic Republic of the Congo (DRC) v. Rwanda, concerning armed activities by the latter on the territory of the Congo. The application, filed in May 2002, related to, inter alia, massive and flagrant violations of human rights and of international humanitarian law, alleged to have been committed "in breach of the 'International Bill of Human Rights', [and] other relevant international instruments and mandatory resolutions of the United Nations Security Council”.

In order to persuade the Court that it has jurisdiction, the DRC invoked in its application eleven (!) compromissory clauses from different international conventions. In addition, the DRC contended, inter alia, that the Vienna Convention on the Law of Treaties establishes the jurisdiction of the Court to settle disputes arising from the violation of peremptory norms (ius cogens) in the area of human rights, "as those norms are reflected in a number of international instruments". Further to this, it was claimed by the DRC that Rwanda by 'showing up' accepted the jurisdiction of the Court (forum prorogatum).

In its judgement, the Court found - by fifteen votes to two - that it had no jurisdiction in the case, thereby eliminating all the compromissory grounds one after another, with a range of specific and often very interesting arguments in relation to each Convention. The main, overall argument thereby presented is the classical one: "When a compromissory clause in a treaty provides for the Court's jurisdiction, that jurisdiction exists only in respect of the parties to the treaty who are bound by that clause and within the limits set out therein". Despite the fact that the jurisdiction has not been accepted, the judgement contains many interesting observations and arguments, which would not be ill-suited in a handbook on international law. In the present contribution, I would like to focus upon two elements only: First, the DRC's claim in relation to the ius cogens character of the norms of, inter alia, the Genocide Convention and what this would mean in relation to the acceptance of the Court's jurisdiction, and, secondly, the DRC's claim of forum prorogatum. The underlying question is: To what extent are states free to deny the jurisdiction of the Court, if it is about the peremptory part of the international legal order? 
As to the forum prorogatum issue, the DRC has argued that the willingness of a State to submit a dispute to the Court may be apparent not only from an express declaration but also "from any conclusive act, in particular from the conduct of the respondent State subsequent to seisin of the Court”. The DRC has argued, in more detail, that Rwanda's agreement to plead implies that it accepts the Court's jurisdiction. The latter, according to the DRC, included the fact that Rwanda has "complied with all the procedural steps prescribed or requested by the Court", that it has "fully and properly participated in the different procedures in this case, without having itself represented or failing to appear", and that "it has not refused to appear before the Court or to make submissions".

In its judgement on this issue the Court recalls its standing jurisprudence, stating that "neither the Statute nor the Rules require that this consent should be expressed in any particular form", and "there is nothing to prevent the acceptance of jurisdiction (...) from being effected by two separate and successive acts, instead of jointly and beforehand by a special agreement”. However, in the present case, the Court raised the question whether Rwanda's attitude can be seen as "an unequivocal indication" of its desire to accept the Court's jurisdiction in a "voluntary and indisputable” manner. The Court's conclusion: Rwanda has expressly and repeatedly objected to its jurisdiction at every stage of the proceedings, thereby recognising Rwanda's argument that it has appeared before the Court solely for the purpose of challenging that jurisdiction.

So far so good, but these things are never that simple. The dissenting opinion by Judge Koroma sheds a new light on the issue. He agrees to the judgement that it is a principle of law that the jurisdictional basis of the Court is consensual and that such consent may take various forms, one of which is forum prorogatum. He then states, however: "While I do not accept the substance of the DRC's argument on this issue, I do believe that the gravity of the matter and the nature of the allegation before the Court are such that the Court should have been allowed to adjudicate the case." He then goes to elaborate: "The Court has over the years taken cognizance of the importance of the Genocide Convention, has acknowledged the denial of humanity that genocide described as the 'crime of all crimes' represents, and has responded appropriately, declaring 'the principles underlying the Convention' to be 'principles which are recognized by civilized nations as binding on States, even without any conventional obligation."' Reaching such profound conclusions, the Court, according to Judge Koroma, "was reflecting the gravity of the crime of genocide and the seriousness with which it, the international community and mankind as a whole take the Convention". And "while not denying the right of the States parties to the Convention to enter reservations to Article IX, 1 the Court, through its jurisprudence, has stressed the unique nature of the Convention and the necessity for States to respect their obligations under it.” Judge Koroma concludes then that "the Court's pronouncements fostered high hopes and expectations that the object and purpose of the Convention would be fulfilled. This case presented an opportunity for the Court to apply the Convention and its principles.”

\footnotetext{
${ }^{1}$ Article IX says: "Disputes between the Contracting Parties relating to the interpretation, application or fulfilment of the Convention, including those relating to the responsibility of a State for genocide (...) shall be submitted to the International Court of Justice at the request of any of the parties to the dispute.”
} 
In Judge Koroma's words it is this "profound respect for the Court's earlier affirmations of the principle underlying the Convention, its object and purpose, together with the seriousness of the matter before it", which led him to regret the Court's conclusion that it is not entitled to take on the present case. Thereby he feels supported by the joint separate opinion of Judges Higgins, Kooijmans, Elaraby, Owada and Simma. In Judge Koroma's opinion, those Judges have "succinctly reflected the essence of the judicial concern underlying this opinion, namely, that it is a very grave matter for a State to shield itself from international judicial scrutiny for 'any claim that might be made against it concerning genocide. A State so doing shows the world scant confidence that it would never, ever, commit genocide, one of the greatest crimes known”. The five Judges themselves, however, have reached a different conclusion. They state indeed that it "is a matter for serious concern that at the beginning of the twenty-first century it is still for States to choose whether they consent to the Court adjudicating claims that they have committed genocide", that "it must be regarded as a very grave matter that a State should be in a position to shield from international judicial scrutiny any claim that might be made against it concerning genocide", and that "judicial settlement of claims relating to genocide is highly desirable". It cannot be said, however, according to the five judges, that "the entire scheme of the Genocide Convention would necessarily collapse if some States make reservations to Article IX. Were it so, adherence to the jurisdiction of the Court could have been made compulsory". Nevertheless, their common opinion ends with words that are worth being underlined: "It is thus not self-evident that a reservation to Article IX could not be regarded as incompatible with the object and purpose of the Convention and we believe that this is a matter that the Court should revisit for further consideration." (Italics added) The door is left open, so to speak, although opening it any further came too early for the present case. Nevertheless, the consensual, voluntary basis of accepting the Court's jurisdiction is at least questioned, which creates hope for the future as to possible new approaches to the acceptance of the Court's jurisdiction.

\footnotetext{
${ }^{*}$ Willem van Genugten is a Professor of International Law at Tilburg University in the Netherlands
} 